\title{
EFFECTIVENESS OF ASCORBIC ACID AND PVP IN THE ROOTING OF CLONAL MINI-CUTTINGS OF Eucalyptus urophylla x Eucalyptus grandis
}

\author{
Lucas Amaral de Meloํㅜ, Aloisio Xavier², Elizabete Keiko Takahashi \\ Antônio Marcos Rosado ${ }^{4}$, Haroldo Nogueira de Paiva ${ }^{5}$
}

(received: November 17, 2009; accepted: June 30, 2011)

\begin{abstract}
The objective of this study is to evaluate the effectiveness of the antioxidants ascorbic acid and polyvinylpyrrolidone (PVP) in the rooting of mini-cuttings for three clones of Eucalyptus urophylla $\mathrm{x}$ Eucalyptus grandis. Mini-cuttings were gathered from a mini-clonal hedge which had been cultivated in concrete ducts containing washed sand. Five concentrations of each antioxidant were experimentally tested on each of the three clones $\left(\mathrm{C}_{1}, \mathrm{C}_{2}\right.$ and $\left.\mathrm{C}_{3}\right)$. Assessments were done of mini-cutting survival and rooting rates when leaving the greenhouse and the shade house, as well as seedling survival and growth at age 50 days. Ascorbic acid was found to be beneficial to the mini-cuttings of the clone with a lower rooting percentage $\left(\mathrm{C}_{3}\right)$, whereas PVP was found to be unbeneficial to the clones being studied.
\end{abstract}

Key words: Mini-cutting technique, antioxidants, clonal forestry.

\section{EFICIÊNCIA DO ÁCIDO ASCÓRBICO E PVP NO ENRAIZAMENTO DE MINIESTACAS DE CLONES DE Eucalyptus urophylla x Eucalyptus grandis}

RESUMO: Objetivou-se, com este estudo, avaliar a eficiência dos antioxidantes ácido ascórbico e polivinilpirrolidona (PVP) no enraizamento de miniestacas de três clones de Eucalyptus urophylla x Eucalyptus grandis. As miniestacas foram coletadas em minijardim clonal, conduzido em canaletas de alvenaria preenchidas com areia lavada. Experimentalmente, foram testadas cinco concentrações de cada antioxidante nos três clones estudados $\left(C_{l}, C_{2}\right.$ e $\left.C_{3}\right)$. Foram realizadas avaliações de sobrevivência e enraizamento de miniestacas na saída das casas de vegetação e de sombra e da sobrevivência e crescimento das mudas aos 50 dias de idade. A utilização do ácido ascórbico foi favorável para as miniestacas do clone com menor porcentual de enraizamento $\left(C_{3}\right)$, porém, a utilização do PVP mostrou-se desfavorável para os clones estudados.

Palavras-chave: Miniestaquia, antioxidantes, silvicultura clonal.

\section{INTRODUCTION}

The search for improved effectiveness in the production of nursery seedling has stimulated forestry companies to seek alternative techniques and to improve already established techniques. According to Xavier et al. (2009), knowledge of the finest vegetative propagation techniques in combination with use of substances capable of stimulating rooting can both contribute to make better use of vegetative material and thus lead to productivity gains.

In the Brazilian forest sector, mini-cutting technique is today the most commonly used method for vegetative propagation of eucalyptus. This technique comprises several phases, which include: shoot production in a mini-clonal hedge, induction of adventitious roots in a climatized greenhouse, acclimatization in a shade house, seedling growth and hardening (ALFENAS et al., 2009; ASSIS et al., 2004; HIGASHI et al., 2000; XAVIER et al., 2009; XAVIER; WENDLING, 1998). Optimizing operations in each of these phases will help achieve success in seedling production (FERREIRA et al., 2004).

Countless factors can affect the rhizogenic process, including influence of species/clone, type of cutting, juvenility, hormone balance, presence of root inducers and inhibitors, effect of collection season, rooting environment and influence of nutritional status (XAVIER et al., 2009).

\footnotetext{
${ }^{1}$ Forest Engineer, PhD Candidate in Forest Engineering - Departamento de Ciências Florestais - Universidade Federal de Lavras - Cx. P. 3037 37200-000 - Lavras, MG, Brazil - lucas.amaral@ufv.br

${ }^{2}$ Forest Engineer, Professor PhD in Forest Science - Departamento de Engenharia Florestal - Universidade Federal de Viçosa - 36570-000 - Viçosa, MG, Brazil-xavier@ufv.br

${ }^{3}$ Biologist, PhD in Agronomy (Plant Genetics and Improvement) - CENIBRA - Celulose Nipo Brasileira S.A. - Rodovia de Ligação, BR 381 a Belo Oriente -35195-000 - Belo Oriente, MG, Brazil - elizabete.takahashi@cenibra.com.br

${ }^{4}$ Forest Engineer, PhD in Genetics and Improvement - CENIBRA - Celulose Nipo Brasileira S.A. - Rodovia de Ligação, BR 381 a Belo Oriente 35195-000 - Belo Oriente, MG, Brazil - antonio.rosado@cenibra.com.br

${ }^{5}$ Forest Engineer, Professor PhD in Agronomy/Plant Science - Departamento de Engenharia Florestal - Universidade Federal de Viçosa - 36570-000 Viçosa, MG, Brazil - hnpaiva@ufv.br
}

Cerne, Lavras, v. 17, n. 4, p. 499-507, out./dez. 2011 
Certain substances at different concentrations, combined with the time elapsed between collecting and actually planting the mini-cuttings, may impact propagule rooting due to reactions occurring in the vegetative material, for instance oxidation (WENDLING et al., 2000b).

Oxidation on the base of mini-cuttings affects the entire rhizogenic process, yet it can be minimized or even avoided by adopting some procedures, for instance using antioxidant substances, reducing mechanical damage and washing vegetative propagules under running water (WENDLING, 2002). Effects of antioxidants include inactivation of free radicals, complexometry of metabolic ions or reduction of peroxides for products unable to form free radicals with potential to oxidize (ARAÚJO, 2008).

Antioxidative substances include ascorbic acid, polyvinylpyrrolidone-PVP (HANDA et al., 2005), citric acid (HARTMANN et al., 2002) and activated charcoal (MELO et al., 2001). Their use is often reported in micropropagation, however it is still very restricted in the rooting of vegetative cuttings (FACHINELLO et al., 1993).

While studying the effect of ascorbic acid and PVP on rooting of mini-cuttings in four clones of Eucalyptus spp., Goulart (2007) concluded that ascorbic acid was only effective in one clone, whereas PVP was effective in all clones in maximizing the rooting of mini-cuttings.

Ascorbic acid reacts with metals present in the culture medium, preventing them from being available to oxidize (TAIZ; ZEIGER, 2004), and its use has reduced explant oxidation in tissue culture (SOUZA; ABREU, 2007; ZIV; HALEVY, 1983). Similar results were found by Pasqual et al. (2002) using PVP. According to Teixeira (2001), PVP is an adsorbent compound that binds to phenols and prevents oxidation, in addition to adsorbing the products of phenol oxidation. All that considered, the objective of this study is to evaluate effectiveness of the antioxidants ascorbic acid and PVP in the rooting of mini-cuttings of three clones of Eucalyptus urophylla $\mathrm{x}$ E. grandis.

\section{MATERIAL AND METHODS}

\subsection{Experimental material}

This work was carried out from September to November 2008, in the forest nursery of Celulose Nipo-Brasileira S.A. - CENIBRA, a company located in Belo Oriente, Minas Gerais. The municipality of Belo Oriente lies in Vale do Rio Doce and has a Cwa climate (subtropical, rainy and temperate) according to Köppen classification, located at geographical coordinates $19^{\circ} 18^{\prime} 23^{\prime \prime}$ south latitude and $42^{\circ} 22^{\prime} 46^{\prime \prime}$ west longitude, at and altitude of $363 \mathrm{~m}$. The average annual precipitation is $1,233 \mathrm{~mm}$ and the average annual temperature is $21^{\circ} \mathrm{C}$, with highs of $27^{\circ} \mathrm{C}$ and lows of $14^{\circ} \mathrm{C}$.

Mini-cuttings of three clones of Eucalyptus urophylla $\times$ E. grandis were used, as collected from mini-stumps established in a mini-clonal hedge, following management and nutrition procedures adopted by CENIBRA. The criterion of clone selection was based on average rooting percentages. Selection included one clone with rooting percentage above $90 \%\left(\mathrm{C}_{1}\right)$, one clone with rooting percentage between $80 \%$ and $90 \%\left(\mathrm{C}_{2}\right)$ and one clone with rooting percentage below $80 \%\left(\mathrm{C}_{3}\right)$.

\subsection{Mini-clonal hedge management}

According to the mini-cutting technique described by Alfenas et al. (2009), Assis et al. (2004), Higashi et al. (2000), Wendling et al. (2000a), Xavier et al. (2009) and Xavier and Wendling (1998), and according to management procedures adopted by CENIBRA, the miniclonal hedge consisted of mini-stumps obtained through the rooting of mini-cuttings introduced in concrete ducts, previously lined with gravel and topped with washed sand.

An automated system of drip fertirrigation was used for plant irrigation and mineral nutrition, according to the operating procedures adopted by CENIBRA. The system was activated every three hours and left to irrigate for six minutes.

\subsection{Mini-cutting collection, preparation and planting}

The collection, preparation and planting of minicuttings took place on September 18, 2008, soon after the start of nursery activities, at 8:30.

Mini-cuttings around six to eight inches in length were collected and prepared, maintaining two pairs of leaves reduced to half the original size. In order to maintain turgidity conditions, the mini-cuttings were placed in polysterene boxes and sprinkled with water by using a manual sprayer, at time intervals of less than five minutes until the planting stage.

Once prepared, the mini-cuttings were treated with the antioxidants ascorbic acid or PVP, prior to being planted and left to root in the climatized greenhouse. The following concentrations were used: ascorbic acid $(0,10$, 20, 40 and $\left.80 \mathrm{mg} \mathrm{L}^{-1}\right)$ and PVP $(0,2000,4000,8000$ and $\left.16000 \mathrm{mg} \mathrm{L}^{-1}\right)$, diluted in distilled water. The base portions of the mini-cuttings $(2 \mathrm{~cm})$ were dipped in the antioxidant solution for 15 seconds and then planted in the substrate. The time interval between collecting, preparing, applying antioxidant and planting the mini-cuttings was invariably less than 30 minutes.

Cerne, Lavras, v. 17, n. 4, p. 499-507, out./dez. 2011 
The mini-cuttings were planted in a substrate consisting of combined scorched rice husk and vermiculite (1:1), enriched with $8000 \mathrm{~g} \mathrm{~m}^{-3}$ of simple superphosphate, $694 \mathrm{~g} \mathrm{~m}^{-3}$ of ammonium sulfate, $208 \mathrm{~g} \mathrm{~m}^{-3}$ of potassium chloride, $13.9 \mathrm{~g} \mathrm{~m}^{-3}$ of zinc sulfate, $13.9 \mathrm{~g} \mathrm{~m}^{-3}$ of copper sulfate, $13.9 \mathrm{~g} \mathrm{~m}^{-3}$ of manganese sulfate and $27.8 \mathrm{~g} \mathrm{~m}^{-3}$ of boric acid, according to operating procedures adopted by CENIBRA. Tapered plastic tubes were used as containers, each $12 \mathrm{~cm}$ in length and with a capacity of $55 \mathrm{~cm}^{3}$, previously sterilized in hot water at $80^{\circ} \mathrm{C} / 30$ sec., according to the method described by Alfenas et al. (2009).

The process of mini-cutting rooting was conducted in the climatized greenhouse of the forest nursery, set to a temperature of around $27^{\circ} \mathrm{C}$ and relative humidity above $80 \%$, for a period of 18 days. The mini-cuttings were then transferred to a shaded area receiving around $50 \%$ of light intensity as obtained in an outdoor environment by using a shade screen (remaining there for 10 days to acclimatize), and finally taken to the growth area under sunlight until they reached 50 days of development.

Independent experiments were set up to evaluate the effect of each antioxidant on the rooting of the clonal mini-cuttings of Eucalyptus urophylla x E. grandis. Both experiments followed a completely randomized experimental design, using a $3 \times 5$ factorial arrangement, considering all three clones being studied $\left(\mathrm{C}_{1}, \mathrm{C}_{2}\right.$ and $\mathrm{C}_{3}$ ) and five antioxidant dosages, in five replicates of 32 plants each, to a total of 800 mini-cuttings per clone in each experiment.

\subsection{Experimental evaluations}

Plants were evaluated as to the percentage of minicutting survival when leaving the greenhouse (18 days after planting), percentage of mini-cutting survival and percentage of mini-cuttings with roots longer than $10 \mathrm{~cm}$ (with roots sprouting out of the plastic tube base) when leaving the shade house (28 days after planting). At age 50 days, evaluations included percentage of survival, height $(\mathrm{cm})$ and stem base diameter $(\mathrm{mm})$ of seedlings.

In order to measure height and stem base diameter of seedlings at age 50 days, eight randomly picked plants were analyzed per replicate. Height was measured using a ruler marked in $\mathrm{mm}$ and stem base diameter was measured using a Mitutoyo 500-144B digital caliper with a resolution of $0.01 \mathrm{~mm}$.

With data at hand for the relevant traits, analysis of variance and regression procedures were performed. For the ANOVA, statistical application SISVAR was used (FERREIRA, 2000), with data analysis following the methodology proposed by Banzatto and Kronka (2006). Regression equations were developed using software application CurveExpert 1.3 (HYAMS, 1997).

\section{RESULTS AND DISCUSSION}

\subsection{Effectiveness of ascorbic acid}

The analysis of variance revealed a significant effect, by the $\mathrm{F}$ test $(\mathrm{P}<0.05)$, of the 'clone $\mathrm{x}$ treatment' interaction for the traits being assessed, indicating different responses from each clone to various concentrations of ascorbic acid (Table 1).

Table 1 - Analysis of variance results for traits being assessed, as a function of various concentrations of ascorbic acid being used in mini-cuttings of three clones of Eucalyptus urophylla $\mathrm{x}$ E. grandis.

Tabela 1 - Resultados da análise de variância para as características avaliadas em função das concentrações de ácido ascórbico, utilizadas em miniestacas de três clones de Eucalyptus urophylla $x$ E. grandis.

\begin{tabular}{lccccccc}
\hline \multirow{2}{*}{ Source } & DF & \multicolumn{9}{c}{ Mean Square } \\
\cline { 3 - 8 } & & PSCV (\%) & PSCS (\%) & PSCS10 (\%) & PS50 (\%) & ALT (cm) & DC (mm) \\
\hline Clone (C) & 2 & $1.3835^{*}$ & $1.7389^{*}$ & $2.7742^{*}$ & $1.5208^{*}$ & $291.8152^{*}$ & $0.4741^{*}$ \\
Treat. (T) & 4 & $0.0170^{*}$ & $0.0126^{*}$ & $0.0266^{*}$ & $0.0184^{*}$ & $10.4695^{*}$ & $0.0465^{*}$ \\
C x T & 8 & $0.0495^{*}$ & $0.0343^{*}$ & $0.0224^{*}$ & $0.0190^{*}$ & $2.9015^{*}$ & $0.0214^{*}$ \\
Residual & 60 & 0.0040 & 0.0031 & 0.0029 & 0.0035 & 0.6294 & 0.0038 \\
Overall Mean & - & 95.2 & 92.5 & 86.9 & 86.9 & 22.5 & 2.7 \\
CV $(\%)$ & - & 4.7 & 4.3 & 4.5 & 4.9 & 3.5 & 2.3 \\
\hline
\end{tabular}

Percentage of mini-cutting survival when leaving the greenhouse (PSCV) and when leaving the shade house (PSCS), percentage of mini-cuttings with roots longer than $10 \mathrm{~cm}$ when leaving the shade house (PSCS10), survival percentage (PS50), height (ALT) and stem base diameter (DC) of seedlings at the end of the growth period ("*" = significant at the $5 \%$ probability level, by the F test).

Cerne, Lavras, v. 17, n. 4, p. 499-507, out./dez. 2011 
Survival rates for clones $\mathrm{C}_{1}$ and $\mathrm{C}_{2}$ were found to be above $90 \%$ when leaving the greenhouse and the shade house, irrespective of the concentration of ascorbic acid being used, which demonstrates a high percentage of mini-cutting usability in both and thus indicates that applying ascorbic acid in these clones is unnecessary. Survival rates for clone $\mathrm{C}_{3}$ were found to be below the rates found for the other clones, yet this clone proved positively influenced by dosages of up to $40 \mathrm{mg} \mathrm{L}^{-1}$ of ascorbic acid (Figure 1).
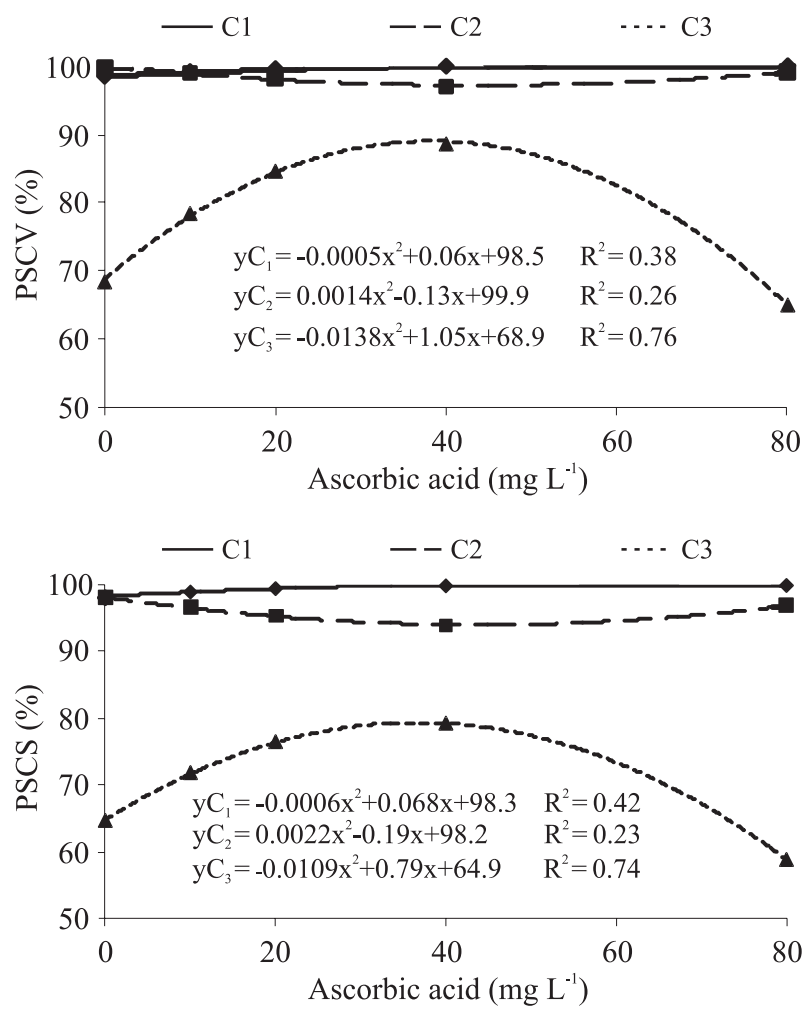

Figure 1 - Percentage of mini-cutting survival when leaving the greenhouse (PSCV) and when leaving the shade house (PSCS), as a function of ascorbic acid use, for the three clones of Eucalyptus urophylla $\mathrm{x}$ E. grandis $\left(\mathrm{C}_{1}, \mathrm{C}_{2}\right.$ and $\left.\mathrm{C}_{3}\right)$.

Figura 1 - Porcentual de sobrevivência de miniestacas na saída da casa de vegetação (PSCV) e na saída da casa de sombra (PSCS), em função da aplicação de ácido ascórbico, dos três clones de Eucalyptus urophylla $x$ E. grandis $\left(C_{1}, C_{2}\right.$ e $\left.C_{3}\right)$.

Despite the differences in rooting percentages among clones, the traits mini-cuttings with roots longer than $10 \mathrm{~cm}$ (PSCS10) and seedling survival at age 50 days (PS50) followed a similar pattern (Figure 2).

Cerne, Lavras, v. 17, n. 4, p. 499-507, out./dez. 2011
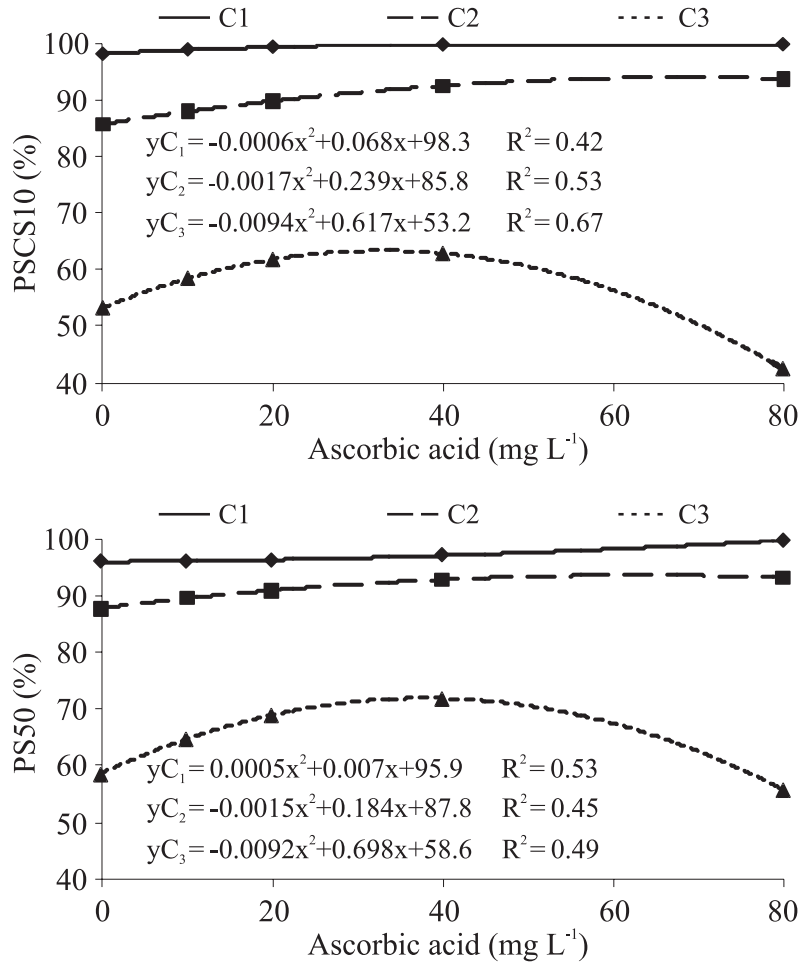

Figure 2 - Percentage of mini-cuttings with roots longer than $10 \mathrm{~cm}$ when leaving the shade house (PSCS10) and percentage of seedling survival at age 50 days (PS50), as a function of acid ascorbic use, for the three clones of Eucalyptus urophylla $\mathrm{x} E$. grandis $\left(\mathrm{C}_{1}, \mathrm{C}_{2}\right.$ and $\left.\mathrm{C}_{3}\right)$.

Figura 2 - Porcentual de miniestacas com raizes maiores que $10 \mathrm{~cm}$ na saída da casa de sombra (PSCS10) e porcentual de sobrevivência de mudas aos 50 dias de idade (PS50), em função da aplicação de ácido ascórbico, dos três clones de Eucalyptus urophylla $x$ E. grandis $\left(C_{1}, C_{2} e C_{3}\right)$.

Judging by results in Figure 2, once again the use of ascorbic acid proved unnecessary for clones $\mathrm{C}_{1}$ and $\mathrm{C}_{2}$, since values for traits being assessed were found to be above $96 \%$ and $87 \%$ respectively, denoting no significant increment with increasing dosages of antioxidant. Any losses occurring throughout the process for these clones are unlikely due to mini-cutting oxidation.

Under the influence of ascorbic acid, the minicuttings of clone $\mathrm{C}_{3}$ showed increased rooting and survival percentages if compared to the mini-cuttings of other genotypes being studied, which demonstrates antioxidant effectiveness for this clone (Figures 1 and 2). Antioxidant use in the mini-cuttings of clone $\mathrm{C}_{3}$ was found to have a beneficial effect up to concentrations of $40 \mathrm{mg} \mathrm{L}^{-1}$, with dosages higher than that decreasing trait values. 
An analysis of growth traits reveals that once again clones $\mathrm{C}_{1}$ and $\mathrm{C}_{2}$ have similarities, especially in that both show higher values of height and stem base diameter of seedlings than clone $\mathrm{C}_{3}$. As regards seedling height at 50 days, overall all clones were negatively influenced by ascorbic acid use. And as regards stem base diameter, $\mathrm{C}_{1}$ was the only clone showing increased values for this trait with dosages above $20 \mathrm{mg} \mathrm{L}^{-1}$ (Figure 3).
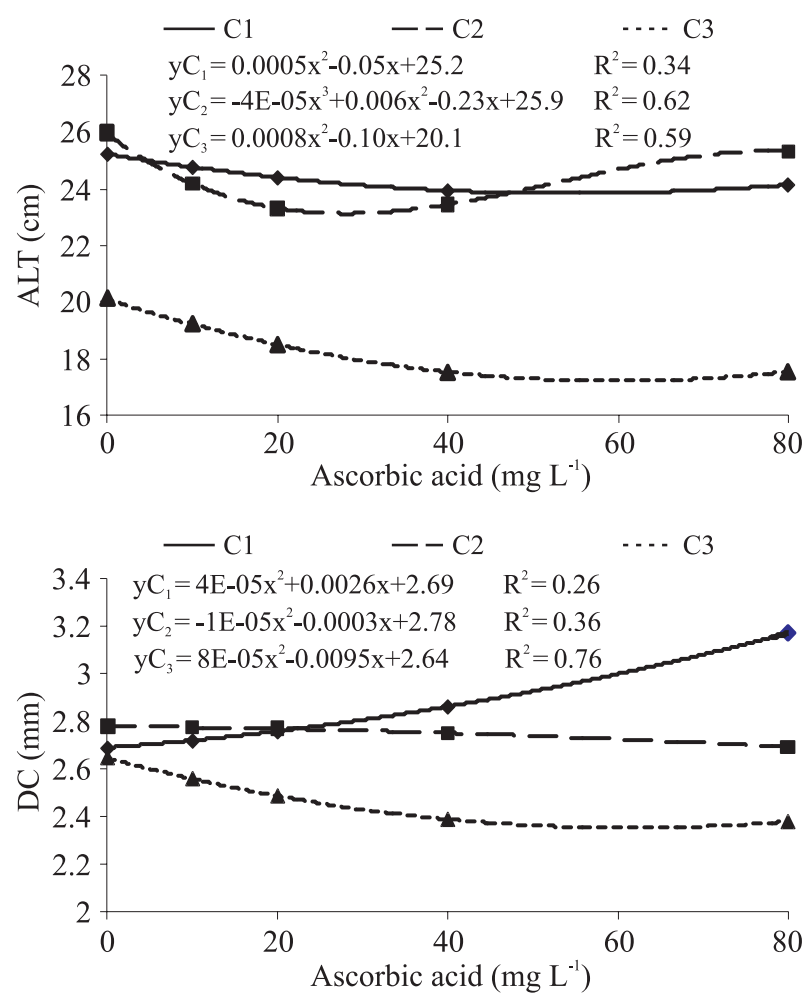

Figure 3 - Height (ALT) and stem base diameter (DC) of seedlings at age 50 days, as a function of ascorbic acid use, for the three clones of Eucalyptus urophylla $\mathrm{x}$ E. grandis $\left(\mathrm{C}_{1}, \mathrm{C}_{2}\right.$ and $\left.\mathrm{C}_{3}\right)$.

Figura 3 - Altura (ALT) e diâmetro de colo (DC) de mudas aos 50 dias de idade, em função da aplicação de ácido ascórbico, dos três clones de Eucalyptus urophylla $x$ E. grandis $\left(C_{1}, C_{2}\right.$ e $\left.C_{3}\right)$.

At age 50 days, measurements of height and stem base diameter of seedlings were found to be within minimum quality standards commonly used by the forestry sector (height between $20 \mathrm{~cm}$ and $30 \mathrm{~cm}$ and diameter above $2 \mathrm{~mm}$ ). Only in clone $\mathrm{C}_{3}$ were height measurements below $20 \mathrm{~cm}$ (Figure 3). Prior to being transferred to the field, after age 50 days, seedlings are taken to the hardening area of the nursery, a place whose management characteristics do not favor heightwise growth.
Therefore, the seedlings of clone $\mathrm{C}_{3}$ need to remain longer in the nursery in order to achieve minimum quality standards concerning height, or else they need to be subjected to management procedures capable of boosting height throughout the initial 50 days. According to Carneiro (1995), seedling height is an easily modifiable trait, depending on the management procedure being used in the nursery.

On the whole, application of ascorbic acid is not justifiable for the mini-cutting technique in clones $\mathrm{C}_{1}$ and $\mathrm{C}_{2}$. In $\mathrm{C}_{3}$ (Figures 1 and 2), however, which is the clone showing lower rooting and survival percentages, gains from using that antioxidant are expressive, in comparison with the other clones.

Use of ascorbic acid failed to increase usability percentages of mini-cuttings in clones $\mathrm{C}_{1}$ and $\mathrm{C}_{2}$ (Figures 1 and 2). Additionally, time spent in treating mini-cuttings with the antioxidant solution should also be computed, as this factor reduces propagule productivity during one day of work.

Results reveal that one of the limiting factors to the mini-cutting technique in clone $\mathrm{C}_{3}$ is the oxidation of its mini-cuttings, owing to the fact that with concentrations of up to $40 \mathrm{mg} \mathrm{L}^{-1}$ of ascorbic acid it was possible to increase the survival percentage of seedlings at 50 days, in comparison with the treatment without the antioxidant (Figure 2).

While investigating the rooting of five hybrid clones of Eucalyptus grandis, Melo (2009) noticed the occurrence of oxidation on the base of mini-cuttings in one of the clones and thus concluded that for that reason many mini-cuttings would die before the rooting process was completed, and root formation in those that did survive occurred above the oxidized area, delaying the process of seedling formation.

\subsection{Effectiveness of PVP}

The analysis of variance revealed a significant effect, by the $\mathrm{F}$ test $(\mathrm{P}<0.05)$, of the 'clone $\mathrm{x}$ treatment' interaction on traits being assessed, indicating different responses from each clone to various PVP concentrations (Table 2).

For clones $\mathrm{C}_{1}$ and $\mathrm{C}_{2}$, survival rates when leaving the greenhouse and the shade house were found to be above $90 \%$ in the absence of PVP, denoting a high percentage of mini-cutting usability in both. For clone $\mathrm{C}_{2}$, however, when the antioxidant was used a decrease was observed in the values of relevant traits, particularly at concentrations above $8000 \mathrm{mg} \mathrm{L}^{-1}$. The same occurred with clone $\mathrm{C}_{1}$

Cerne, Lavras, v. 17, n. 4, p. 499-507, out./dez. 2011 
Table 2 - Analysis of variance results for traits being assessed, as a function of various concentrations of the antioxidant PVP being used in mini-cuttings of three clones of Eucalyptus urophylla $\mathrm{x}$ E. grandis.

Tabela 2 - Resultados da análise de variância para as características avaliadas, em função das concentrações do antioxidante PVP utilizadas em miniestacas de três clones de Eucalyptus urophylla x E. grandis.

\begin{tabular}{lccccccc}
\hline \multirow{2}{*}{ Source } & DF & \multicolumn{9}{c}{ Mean Square } \\
\cline { 3 - 8 } & & PSCV (\%) & PSCS (\%) & PSCS10 (\%) & PS50 (\%) & ALT (cm) & DC (mm) \\
\hline Clone (C) & 2 & $2.3325^{*}$ & $2.2931^{*}$ & $3.1423^{*}$ & $2.7400^{*}$ & $0.7335^{*}$ & $218.3248^{*}$ \\
Treat. (T) & 4 & $0.1036^{*}$ & $0.1085^{*}$ & $0.1299^{*}$ & $0.1317^{*}$ & $0.0998^{*}$ & $22.2665^{*}$ \\
C x T & 8 & $0.0515^{*}$ & $0.0520^{*}$ & $0.0817^{*}$ & $0.0493^{*}$ & $0.0624^{*}$ & $7.2327^{*}$ \\
Residual & 60 & 0.0034 & 0.0028 & 0.0038 & 0.0030 & 0.0078 & 0.7879 \\
Overall Mean & - & 88.2 & 82.9 & 72.6 & 70.5 & 2.7 & 22.0 \\
CV (\%) & - & 4.8 & 4.6 & 6.1 & 5.5 & 3.3 & 4.0 \\
\hline
\end{tabular}

Percentage of mini-cutting survival when leaving the greenhouse (PSCV) and when leaving the shade house (PSCS), percentage of mini-cuttings with roots longer than $10 \mathrm{~cm}$ when leaving the shade house (PSCS10), survival percentage (PS50), height (ALT) and stem base diameter (DC) of seedlings at the end of the growth period. ( “*” = Significant at the 5\% probability level by the F test)

regarding the trait PSCS, yet to a lesser degree if compared to the pattern in clone $\mathrm{C}_{2}$. In clone $\mathrm{C}_{3}$, survival percentages were found to be below values found for the other clones and, despite being positively influenced by dosages above $8000 \mathrm{mg} \mathrm{L}^{-1}$ of PVP, percentages found up to the maximum dosage were lower than values found in the absence of the antioxidant (Figure 4).

An analysis of the data concerning percentage of mini-cuttings with roots longer than $10 \mathrm{~cm}$ when leaving the shade house and percentage of seedling survival at age 50 days (Figure 5) reveals that clone $\mathrm{C}_{2}$ was negatively influenced by PVP use, showing a more pronounced drop at dosages above $4000 \mathrm{~L}^{-1}$. In clone $\mathrm{C}_{1}$, on the other hand, the above traits remained stable, up to dosages of $5000 \mathrm{mg} \mathrm{L}^{-1}$, similarly to results found by Schwengber et al. (2000).

The above results validate results found by Bergo and Mendes (2000) and Coutinho et al. (1992), in that they observed that combined use of PVP and IBA was insufficient to stimulate rooting.

The trend of the curves for mini-cutting rooting and seedling survival at 50 days in clone $\mathrm{C}_{3}$ (Figure 5) was similar to the trend of its curves for mini-cutting survival when leaving the greenhouse and the shade house (Figure 4), validating the claim that PVP application was unfavorable for that clone.

A decreasing trend was observed in growth traits as a function of increasing PVP dosages (Figure 6). Although in clone $\mathrm{C}_{1}$ height was positively influenced by PVP dosages above $8000 \mathrm{mg} \mathrm{L}^{-1}$, the coefficient of determination of the regression analysis for this clone was low, denoting the unreliability of the regression equation found.

Cerne, Lavras, v. 17, n. 4, p. 499-507, out./dez. 2011
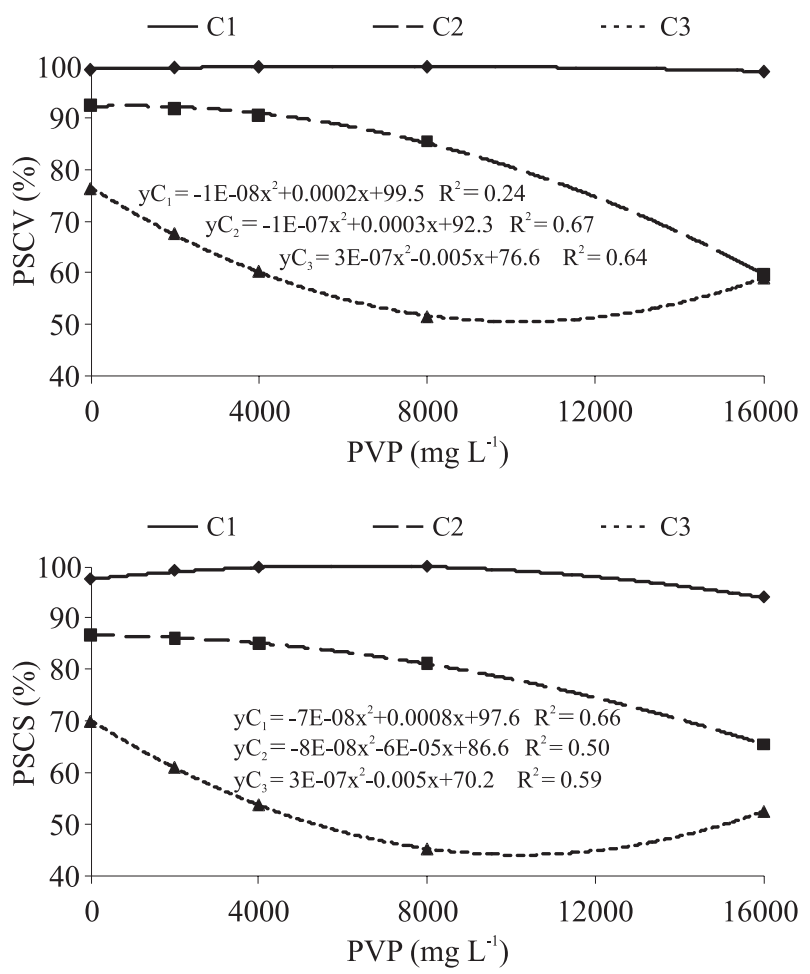

Figure 4 - Percentage of mini-cutting survival when leaving the greenhouse (PSCV) and when leaving the shade house (PSCS), as a function of PVP use, for the three clones of Eucalyptus urophylla $\mathrm{x}$ E. grandis $\left(\mathrm{C}_{1}, \mathrm{C}_{2}\right.$ and $\left.\mathrm{C}_{3}\right)$.

Figura 4-Porcentual de sobrevivência de miniestacas na saída da casa de vegetação (PSCV) e na saída da casa de sombra (PSCS), em função da aplicação de PVP, dos três clones de Eucalyptus urophylla $x$ E. grandis $\left(C_{1}, C_{2} e C_{3}\right)$. 

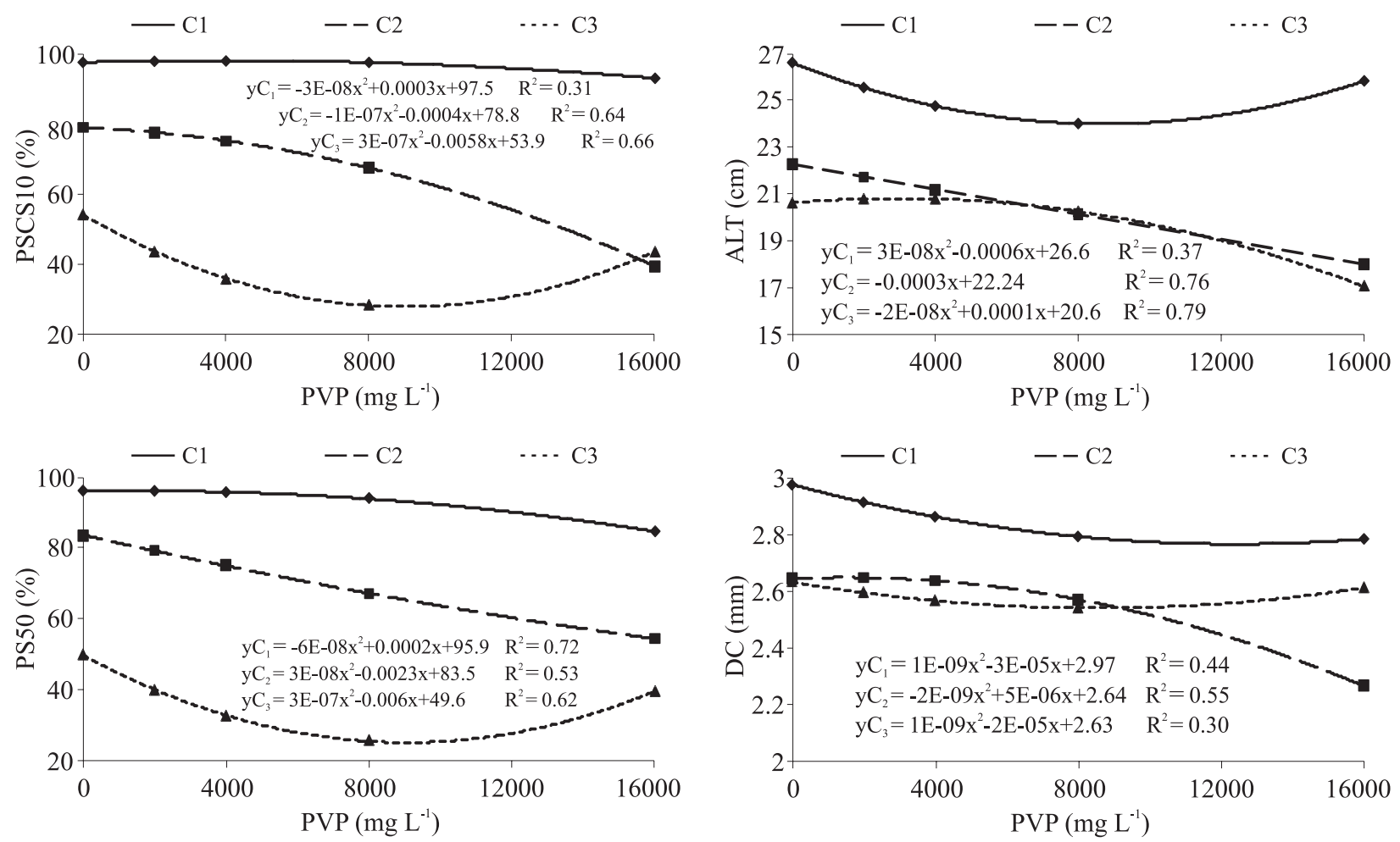

Figure 5 - Percentage of mini-cuttings with roots longer than $10 \mathrm{~cm}$ when leaving the shade house (PSCS10) and survival percentage of seedlings at age 50 days (PS50), as a function of PVP use, for the three clones of Eucalyptus urophylla $\mathrm{x}$ E. grandis $\left(\mathrm{C}_{1}, \mathrm{C}_{2}\right.$ and $\left.\mathrm{C}_{3}\right)$.

Figura 5 - Porcentual de miniestacas com raízes maiores que $10 \mathrm{~cm}$ na saída da casa de sombra (PSCS10) e porcentual de sobrevivência de mudas aos 50 dias de idade (PS50), em função da aplicação de PVP, dos três clones de Eucalyptus urophyllax E. grandis $\left(C_{1}, C_{2}\right.$ e $\left.C_{3}\right)$.

At age 50 days, already some seedlings had height and stem base diameter within the minimum quality standards commonly used by the forestry sector (height between 20 and $30 \mathrm{~cm}$ and diameter above $2 \mathrm{~mm}$ ). For seedlings in clones $\mathrm{C}_{2}$ and $\mathrm{C}_{3}$, however, height results were below $20 \mathrm{~cm}$ with PVP dosages above $4000 \mathrm{mg} \mathrm{L}^{-1}$ (Figure 6), validating the claim that PVP application was unfavorable for the clones.

Results reveal that although oxidation may be a limiting factor for the mini-cutting technique (clone $\mathrm{C}_{3}$ ), the use of any antioxidant should not be regarded as synonymous with increased rooting percentages (Figures 4, 5 and 6). Additionally, in order for the substance to have a positive effect, it is necessary to define the concentration

Figure 6 - Height (ALT) and stem base diameter (DC) of seedlings at age 50 days, as a function of PVP use, for the three clones of Eucalyptus urophylla $\mathrm{x}$ E. grandis $\left(\mathrm{C}_{1}, \mathrm{C}_{2}\right.$ and $\left.\mathrm{C}_{3}\right)$.

Figura 6-Altura (ALT) e diâmetro de colo (DC) de mudas aos 50 dias de idade, em função da aplicação de PVP, dos três clones de Eucalyptus urophylla $x$ E. grandis $\left(C_{1}, C_{2} e C_{3}\right)$.

to be used as function of each species/clone, for instance, while a low concentration may produce unfavorable results for a given genotype, a high concentration may conversely have a toxic effect on the tissues and consequently lead to the death of the vegetative propagule (XAVIER et al., 2009).

On the whole, application of the antioxidant PVP proved unfavorable for the clones being evaluated under the specific experimental conditions of this study (Figures 4, 5 and 6), contrary to results found by Goulart (2007) in which PVP proved effective in the mini-cutting technique for all four clones of Eucalyptus grandis x E. urophylla.

\section{CONCLUSIONS}

Application of antioxidants had different effects on the rooting of mini-cuttings for the three clones of Eucalyptus urophylla $\mathrm{x}$ E. grandis being studied.

Cerne, Lavras, v. 17, n. 4, p. 499-507, out./dez. 2011 
Use of ascorbic acid proved favorable for vegetative propagation of mini-cuttings in clone $\mathrm{C}_{3}$ but unnecessary for their propagation in clones $\mathrm{C}_{1}$ and $\mathrm{C}_{2}$, whereas use of PVP proved unfavorable for all clones being studied.

\section{ACKNOWLEDGMENTS}

The authors wish to thank CENIBRA for facilitating access to experimental material (clones) and for providing structural and budgetary support throughout. They also wish to thank the National Council for Scientific and Technological Development for providing financial support.

\section{REFERENCES}

ALFENAS, A. C. et al. Clonagem e doenças do eucalipto. 2. ed. Viçosa, MG: UFV, 2009. 500 p.

ARAÚJO, J. M. A. Química de alimentos: teoria e prática. 4. ed. Viçosa, MG: UFV, 2008. 596 p.

ASSIS, T. F.; FETT NETO, A. G.; ALFENAS, A. C. Current techiniques and prospects for the clonal propagation of hardwoods with emphasis on Eucalyptus. In: WALTERS, C.; CARSON, M. (Ed.). Plantation forest biotechnology for the $2^{\text {st }}$ century. Delhi: Research Signpost, 2004. p. 303-333.

BANZATTO, D. A.; KRONKA, S. N. Experimentação agrícola. 4. ed. Jaboticabal: FUNEP, 2006. 237 p.

BERGO, C. L.; MENDES, A. N. G. Propagação vegetativa do cafeeiro (Coffea arabica L.) por meio de enraizamento de estacas. Ciência e Agrotecnologia, Lavras, v. 24, n. 2, p. 392398, mar./abr. 2000.

CARNEIRO, J. G. A. Produção e controle de qualidade de mudas florestais. Curitiba: UFPR/FUPEF, 1995. 451 p.

COUTINHO, E. F. et al. Efeito do ácido indolbutírico e antioxidante na formação de calos em estacas semilenhosas de goibeira serrana. Revista Brasileira de Fruticultura, Cruz das Almas, v. 14, n. 3, p. 141-143, 1992.

FACHINELLO, J. C. et al. Efeito do ácido indolbutírico e PVP no enraizamento de estacas de araçazeiro (Psidium cattleyanum Sabine) em diferentes substratos. In: CONGRESSO BRASILEIRO DE FISIOLOGIA VEGETAL, 4., 1993, Fortaleza. Anais... Fortaleza: UFC, 1993. p. 91.

Cerne, Lavras, v. 17, n. 4, p. 499-507, out./dez. 2011
FERREIRA, D. F. Análises estatísticas por meio do SisVar para Windows versão 4.0. In: REUNIÃO ANUAL DA REGIÃO BRASILEIRA DA SOCIEDADE INTERNACIONAL DE BIOMETRIA, 45., 2000, São Carlos. Anais... São Carlos: UFSCAR, 2000. p. 255-258.

FERREIRA, E. M. et al. Determinação do tempo ótimo do enraizamento de miniestacas de clones de Eucalyptus spp. Revista Árvore, Viçosa, v. 28, n. 2, p. 183-187, 2004.

GOULART, P. B. Influência do acondicionamento, antioxidantes, auxinas e seus cofatores no enraizamento de miniestacas de clones de Eucalyptus grandis x E. urophylla. 2007. 115 f. Dissertação (Mestrado em Ciência Florestal) Universidade Federal de Viçosa, Viçosa, 2007.

HANDA, L.; SAMPAIO, P. T. B.; QUISEN, R. C. Cultura in vitro de embriões e de gemas de mudas de pau-rosa (Aniba rosaeodora Ducke). Acta Amazônica, Manaus, v. 35, n. 1, p. 29-33, 2005.

HARTMANN, H. T. et al. Plant propagation: principles and practices. 7. ed. New Jersey: Prentice-Hall, 2002. 880 p.

HIGASHI, E. N.; SILVEIRA, R. L. A.; GONÇALVES, A. N. Propagação vegetativa de Eucalyptus: princípios básicos e a sua evolução no Brasil. Piracicaba: IPEF, 2000. 11 p. (Circular técnica, 192).

HYAMS D. CurveExpert 1.3: a comprehensive curve fitting system for Windows. Starkville, 1997. Software.

MELO, B. et al. Diferentes antioxidantes no controle da oxidação, germinação e desenvolvimento das plântulas na cultura in vitro de embriões da guarirobeira [Syagrus oleracea (MART.) BECC.]. Ciência e Agrotecnologia, Lavras, v. 25, n. 6, p. 1301-1306, nov./dez. 2001.

MELO, L. A. Armazenamento, aplicação de antioxidantes e otimização do tempo em casa de vegetação no enraizamento de miniestacas de híbridos de Eucalyptus grandis. 2009. 49 f. Dissertação (Mestrado em Ciência Florestal) - Universidade Federal de Viçosa, Viçosa, 2009.

PASQUAL, M. et al. Indução de calos em anteras de café (Coffea arabica L.) cultivadas in vitro. Ciência e Agrotecnologia, Lavras, v. 26, n. 1, p. 71-76, jan./fev. 2002. 
SCHWENGBER, J. E.; DUTRA, L.; KERSTEN, E. Efeito do sombreamento da planta matriz e do PVP no enraizamento de estacas de ramos de araçazeiro (Psidium cattleyanum Sabine). Revista Brasileira de Agrociência, Pelotas, v. 6, n. 1, p. 3034, 2000.

SOUZA, K. C. M.; ABREU, H. S. Biotecnologia aplicada ao estudo da lignificação. Floresta e Ambiente, Seropédica, v. 14, n. 1, p. 93-109, 2007.

TAIZ, L.; ZEIGER, E. Fisiologia vegetal. 3. ed. Porto Alegre: Artmed, 2004. 719 p.

TEIXEIRA, J. B. Limitações ao processo de cultivo in vitro de espécies lenhosas. Brasília: Embrapa - Recursos Genéticos e Biotecnologia, 2001. Disponível em: <http://www.redbio. org/portal/encuentros/enc_2001/index.htm>. Acesso em: 10 jan. 2009.

WENDLING, I. Rejuvenescimento de clones de Eucalyptus grandis por miniestaquia seriada e micropropagação. 2002.
98 f. Tese (Doutorado em Ciência Florestal) - Universidade Federal de Viçosa, Viçosa, 2002.

WENDLING, I. et al. Efeito do regulador de crescimento AIB na propagação de clones de Eucalyptus spp. por miniestaquia. Revista Árvore, Viçosa, v. 24, n. 2, p. 187-192, 2000 a.

WENDLING, I. et al. Propagação clonal de híbridos de Eucalyptus spp. por miniestaquia. Revista Árvore, Viçosa, v. 24, n. 2, p. 181-186, 2000 b.

XAVIER, A.; WENDLING, I. Miniestaquia na clonagem de Eucalyptus. Viçosa, MG: SIF, 1998. 10 p. (Informativo técnico SIF, 11).

XAVIER, A.; WENDLING, I.; SILVA, R. L. Silvicultura clonal: princípios e técnicas. Viçosa, MG: UFV, 2009. 272 p.

ZIV, M.; HALEVY, A. H. Control of oxidative browning and in vitro propagation of Strelitzia reginae. HortScience, Alexandria, v. 18, n. 4, p. 434-436, 1983.

Cerne, Lavras, v. 17, n. 4, p. 499-507, out./dez. 2011 
